\title{
ДОСЛІДЖЕННЯ ОСОБЛИВОСТЕЙ МЕНТАЛЬНОСТІ ПОКОЛІНЬ
}

\begin{abstract}
Для створення передумов оптимізації взаєморозуміння і розширення можливостей діалогічного поколінного спілкування представлено методичну базу та опис дослідження особливостей ментальності поколінь. Визначено й обгрунтовано напрямки дослідження особливостей ментальності поколінь: характеристик вибірки щодо соціокультурного історичного ареалу, особливостей соціально-психологічних відмінностей габітусу та соціального позиціонування (ентелехій) поколінь. Відповідно до сформованих критеріїв диференціації і функціональних меж поколінь у результаті кластеризації масиву експериментальних даних виокремлено три покоління - Дітей, Батьків, Прабатьків. Проаналізовано особливості соціально-психологічних відмінностей габітусу і соціального позиціонування (ентелехій) поколінь. Визначено узагальнені характеристики ментальності поколінь, завдяки чому підтверджено припущення щодо унікальності і впливовості ментальних особливостей поколінь, сформованих під впливом історичних подій, на результативність відносин.

Ключові слова: покоління, ментальність, критерії диференціації, соціальні позиції (ентелехії), габітус.
\end{abstract}

Проблема. Трансформація традиційних сфер життєдіяльності громадян України актуалізувала соціальний запит щодо розв'язання проблеми міжпоколінних стосунків, пошуку засобів оптимізації взаємодії для досягнення взаєморозуміння, адже покоління не існують статично, постійно змінюються в багатоетапному пізнанні соціальних законів, поступових змінах поколінного світобачення, трансформації поколінних цінностей, зміні ролей.

Науковий пошук універсальних комунікативних закономірностей, методів і засобів оптимізації відносин довів значення дослідження особливостей ментальності поколінь, які є сукупністю реальних індивідів, об'єднаних загальними поколінними характеристиками, соціальними позиціями. Адже покоління постає як самостійний суб'єкт соціальної поведінки, а ії базовою ознакою є збіг соціальних настановлень, соціальних уявлень, цінностей у хронологічному контексті міжчасового простору або обмеженому часі актуальних традицій, культури, субкультури поколінь. Покоління як соціальна група являє собою форму життя суспільства, біологічні, культурні, соціальні конотації якої охоплюють зміни циклів розвитку і занепаду поколінь конкретного суспільства, конкретної держави. I хоча "безособистісна поколінна група надзвичайно слабко впливає на окрему людину” [1], алвнутрішні абстрактні сили макрорівня соціального існування [2] під 
впливом значущих історичних подій поступово формують ментальну систему поколінь як груп осіб, народжених протягом певного інтервалу часу, і зумовлюють відмінності форм комунікації, характеристик діалогічної взаємодії, особливостей формування діалогічності в міжпоколінних відносинах (стосунках).

Mema cmammi: у контексті вивчення соціальних діалогів у вимірах когнітивного спілкування дослідити особливості ментальності поколінь Дітей, Батьків, Прабатьків, щоб з'ясувати оптимальні форми конструювання технологій взаєморозуміння і розширення можливостей діалогічного поколінного спілкування.

Відповідно до розробленої моделі соціально-психологічного простору поколінь [3] явище поколінної групи ми розглядаємо як результат дії соціально-психологічної системи, продуктом функціонування елементів якої (це соціальні настановлення, соціальні уявлення, цінності поколінь) стає ментальна система поколінь. Адже у світі багатовимірних зв'язків ментальність як онтологічна характеристика зв'язків психологічного і соціального, особливого світобачення і мислення покоління в процесі формотворення поступово окреслює соціальні ролі, дії відповідно до історичних ситуацій, у яких поколінна група стає суб'єктом соціальних відносин, усвідомлених і цілеспрямованих.

I тому напрями дослідження (табл. 1) було визначено 3 огляду на такі позиції: по-перше: для дослідження характеристик ментальності поколінь були сформовані критерії диференціації поколінь, а саме: (1) вікових психологічних характеристик як особливостей психічної організації життєдіяльності людини в мінливому світі на різних етапах онтогенезу; (2) сочзільно-історичних подій, що визначають формування нових зразків моделей відносин, поведінки в процесі пристосування до змін соціальних умов існування; (3) поведінкових стратегій як характеристик, притаманних представникам поколінь у соціокультурному i сімейно-рольовому аспектах. Визначено функціональні межі часової циклічності зміни поколінь залежно від (1) суттєвих соціальноісторичних подій, (2) поколінних якостей, набутих протягом життя, i (3) особливостей відносин (стосунків) [там само].

Узагальненими показниками особливостей поколінь Дітей, Батьків, Прабатьків стали компоненти ментальної системи: соціальні позиції (ентелехії) (визначають положення (статус) поколінь у суспільстві, результативність відносин у міжпоколінному просторі, регламентують поведінку відповідно до умов і ситуацій життєдіяльності) і габітус поколінь (як соціально-психологічна характеристика, яка визначає "образ" покоління в культурно-історичному контексті) $[4$, p. $19 ; 5]$. 
Методична база емпіричного дослідження особливостей ментальності поколінь

\begin{tabular}{|c|c|c|}
\hline Етапи / напрямки дослідження & Завдання / Питання дослідження & $\begin{array}{c}\text { Методи } \\
\text { і методики } \\
\text { дослідження } \\
\end{array}$ \\
\hline $\begin{array}{l}\text { 1. Формування засад дослі- } \\
\text { дження особливостей мента- } \\
\text { льності поколінь }\end{array}$ & $\begin{array}{l}\text { Систематизація критеріїв диференціації і функціональних меж поколінь } \\
\text { Окреслення узагальнених показників особливостей поколінь } \\
\text { (соціальних позицій (ентелехій), габітусу); }\end{array}$ & $\begin{array}{l}\text { Теоретичний } \\
\text { аналіз }\end{array}$ \\
\hline $\begin{array}{l}\text { 2. Визначення характеристи- } \\
\text { ки вибірки щодо соціокуль- } \\
\text { турного історичного ареалу }\end{array}$ & $\begin{array}{l}\text { 1. Межа поширення предмета дослідження } \\
\text { 2. Вік респондентів на час дослідження } \\
\text { 3. Рік народження респондентів } \\
\text { 4. Рік, коли респондентам виповнилося } 18 \text { років } \\
\text { 5. Період в історії держави, який вплинув на формування світобачення } \\
\text { респондентів } \\
\text { 6. Самоідентифікація респондентів за поколінною групою } \\
\text { 7. Самовизначення поколінної ролі респондентів } \\
\end{array}$ & \multirow{4}{*}{$\begin{array}{l}\text { Психодіагно- } \\
\text { стичні } \\
\text { методи } \\
\text { та методи } \\
\text { математичної } \\
\text { обробки } \\
\text { даних }\end{array}$} \\
\hline $\begin{array}{l}\text { 3. Визначення особливостей } \\
\text { соціально-психологічних } \\
\text { відмінностей габітусу } \\
\text { поколінь }\end{array}$ & $\begin{array}{l}\text { 8. Визначення рис, характерних для поколінь Дітей, Батьків, Прабатьків } \\
\text { 9. Самовизначення респондентами характерних рис “свого” покоління } \\
\text { 10. Визначення відмінностей в уявному “образі” поколінь }\end{array}$ & \\
\hline $\begin{array}{l}\text { 4. Визначення особливостей } \\
\text { соціального позиціонування } \\
\text { (ентелехій) поколінь }\end{array}$ & $\begin{array}{l}\text { 11. Визначення життєвих настановлень, уявлень, цінностей, характерних } \\
\text { для поколінь Дітей, Батьків, Прабатьків }\end{array}$ & \\
\hline $\begin{array}{l}\text { 5. Визначення узагальнених } \\
\text { характеристик ментальності } \\
\text { поколінь }\end{array}$ & $\begin{array}{l}\text { Характеристики поколіня Дітей } \\
\text { Характеристики поколіня Батьків } \\
\text { Характеристики поколіня Прабатьків }\end{array}$ & \\
\hline
\end{tabular}


По-друге, за концепцією К. Мангейма [5], осмислення покоління як соціальна група є можливим у разі визначення меж територіального поширення дієвості досліджуваного предмета. Тому, виконуючи зазначену умову, всі опитані респонденти (віком від 16 до 70 років, різного соціального становища й освітніх рівнів, загальною чисельністю 98 осіб) були представниками єдиного соціокультурного історичного ареалу в межах України. Серед опитаних 13,7\% становили чоловіки, 86,3 \% - жінки. Розподіл вибірки опитаних за статтю, на жаль, не був рівномірним, тому гендерного аналізу міжпоколінних відносин (стосунків) проведено не було.

По-третє, щоб дослідити специфічні риси ментальності поколінь, слід виокремити показники міжпоколінних відносин, необхідні для конструювання технологій взаєморозуміння і розширення можливостей діалогічного поколінного спілкування (табл. 1). Це стає можливим, якщо (1) визначити загальні психологічні характеристики поколінь (за такі характеристики було взято габітус як систему диспозицій, що породжують і структурують практики поколінь [4, p. 19], розкривають особливості соціальної ідентичності), як характеристики відмінностей поколінь (історичних продуктів), що проявляється в конкретних історичних умовах в особливостях сприймання, діях, відображається в комунікативних стратегіях поколінь; (2) проаналізувати співвідношення соціально-психологічних відмінностей габітусу поколінь.

По-четверте, у результаті прискорення темпу соціальних i культурних перетворень основні поколінні настановлення змінюються настільки швидко, що латентна, безперервна адаптація і модифікація традиційних моделей досвіду, мислення і вираження стають нефункціональними, у результаті чого відбувається консолідація нових досягнень, досвіду, формується новий імпульс соціальних позицій ентелехії покоління [5]. I тому, враховуючи мінливість поколінних спрямувань і поведінкових принципів щодо соціальних ситуацій існування, наступним напрямом дослідження було визначення особливостей соціального позиціонування (ентелехій) поколінь, відображеного у сформованих соціальних настановленнях, уявленнях, цінностях поколінь.

I, нарешті, позиція щодо узагальнення показників ментальності як складної системи світосприймання і світорозуміння (1) зумовлює відмінності форм суспільних комунікацій, організації соціальної реальності і знаходить своє відображення в особливостях функціонування міжпоколінного комунікативного простору - середовища міжпоколінних відносин (стосунків), (2) пояснює феномен комунікації на перетині 
інформаційних потоків (які покоління транслюють для збереження автентичності ментальної системи поколінь, адже одночасне здійснення різноспрямованих дій: з одного боку - проникнення в іншопоколінні інформаційні потоки для розширення поколінного комунікативного простору, збагачення і розвитку, з другого боку - збереження автентичності ментальної системи поколінь, несвідомого конструювання бар'єрів у відносинах (стосунках)), окреслює способи впорядкування комунікативного простору щодо комунікативного середовища і вибір засобів конструювання міжпоколінного діалогу [1]. I тому визначення узагальнених характеристик ментальних систем поколінь відповідно до внутрішньої логіки взаємовпливовості компонентів результує дослідження особливостей ментальності поколінь щодо формування основ конструювання технологій взаєморозуміння i розширення можливостей діалогічного поколінного спілкування.

Через брак відповідних стандартизованих методик було розроблено авторський опитувальник, спрямований на отримання інформації за основними напрямками дослідження: (1) визначення характеристики вибірки щодо соціокультурного історичного ареалу; (2) визначення соціально-психологічних відмінностей габітусу поколінь; (3) визначення особливостей соціального позиціонування (ентелехій) поколінь.

На етапі вивчення характеристик вибірки щодо соціокультурного історичного ареалу було використано метод кластерного аналізу. Так, для формування поколінних груп 3 максимально схожими проявами змінних використовувалися дані, мінімально залежні від впливів соціального середовища. А саме за критерієм вікових психологічних характеристик було зафіксовано дані показників віку на час проведення опитування; року народження; року, коли респонденти стали повнолітніми (виповнилося 18 років). За критерієм соиіальноісторичних подій використано змінну суб'єктивного визначення респондентами періоду в історії держави, який найбільш значуще вплинув на формування їхнього світосприйняття, світобачення. За критерісм поведінкових стратегій як визначення універсальних характеристик, притаманних представникам поколінь у соціокультурному і сімейнорольовому плані, використано змінні соціальної ідентифікації респондентів 3 певною поколінною групою (Дітей, Батьків, Прабатьків) і рольовим навантаженням у соціальних відносинах (“Діти”, “Діти Батьки”, “Батьки - Прабатьки”, “Прабатьки - Батьки”, “Прабатьки”).

У результаті кластеризації масиву даних за період з 1946 по 2016 роки виокремлено три покоління - Дітей (50,7\%), Батьків $(30,1 \%)$, Прабатьків $(19,1 \%)$, які щодо виконання респондентами со- 
ціальної ролі, історичного періоду становлення були розподілені на п’ять сегментів:

- покоління Прабатьків: виконують відповідну соціальну роль, вік 70-56 років, історичний період становлення - 1964-1982 роки (період “застою - стабільності”) (12,3\% опитаних);

- покоління Прабатьків: виконують соціальні ролі переважно “Прабатьків - Батьків”, вік 55-48 років, історичний період становлення - 1983-1990 роки (період перебудови) (6,8 \% опитаних);

- покоління Батьків: виконують соціальні ролі “Батьків", вік 47-34 років, історичний період становлення - 1991-2003 роки (після отримання Україною незалежності) (30,1\% опитаних);

- покоління Дітей: виконують соціальні ролі “Батьків-Дітей”, вік 33-21 рік, історичний період становлення - 2004-2012 роки (після Помаранчевої революції) (8,2 \% опитаних);

- покоління Дітей: виконують соціальні ролі “Дітей”, вік 20-16 років, історичний період становлення - 2013-2016 роки (після Революції гідності) (42,5\% опитаних). Зазначимо, що процес становлення цього покоління ще не завершений і характеристики габітусу наразі перебувають у процесі формування.

Згідно із загальним припущенням про вплив соціальних умов становлення на особливості ментальних систем поколінь, з огляду на виокремлені соціально-історичні покоління загальну гіпотезу було конкретизовано:

- відмінності габітусу, соціальне позиціонування (ентелехії) створюють унікальну ментальність поколінь, яка може бути представлена у вигляді онтологічної характеристики зв'язків психологічного і соціального;

- на формування характеристик ментальних систем поколінь впливають історичні події, в умовах яких відбувається становлення поколінь.

Отримані в ході опитування аргументовані відповіді респондентів відповідно до положень теоретичних засад дослідження підлягали обробці контент-аналізом, у ході якого враховувалися виокремлені смислові одиниці з частотою згадування понад $9 \%$ показників вільних визначень соціальних позицій (ентелехій), габітусу поколінь які розкривали сутність розуміння респондентами відмінностей характеристик поколінь соціально-психологічного простору.

Відповідно до психологічних механізмів диференціації (порівняння, визначення близьких і відмінних характеристик) та інтеграції (засвоєння групових характеристик, стилю життя) [6] проаналізовано відповіді, отримані на запитання “Які основні риси є характерними для 
покоління Дітей, Батьків, Прабатьків?”. У результаті, незалежно від віку поколінної групи, переважна більшість опитаних характерними якостями покоління Дітей визначили безтурботність (43,2 \%), активність $(32,4 \%)$, завзятість $(29,7 \%)$, велелюбність $(29,7 \%)$, ерудованість $(29,7 \%)$. Якості оптимізму $(17,6 \%)$, незалежності $(17,6 \%)$, самостійності $(17,6 \%)$, дружелюбності $(16,2 \%)$, розкутості $(14,9 \%)$, комунікабельності $(14,9 \%)$, впертості $(10,8 \%)$ як характерні для покоління Дітей відмітили респонденти, які ідентифікують себе 3 поколіннями “Дітей” і “Прабатьків", при цьому представниками покоління Батьків ці якості не були зазначені. Опитані “Прабатьки”, на відміну від інших респондентів, не вважали характерними для покоління Дітей риси безвідповідальності $(20,3 \%)$, легковажності $\quad(16,2 \%)$, допитливості $(14,9 \%)$, цілеспрямованості $(10,8 \%)$. Це можна пояснити більш толерантним, урівноваженим ставленням людей зрілого віку до молоді.

Щодо габітусу покоління Батьків, то відповідальність $(62,2 \%)$, турботливість $(33,8 \%)$, освіченість $(23 \%)$, моральність $(17,6 \%)$, цілеспрямованість $(12,2 \%)$ визнали характерними переважно всі учасники дослідження. Цікаво, що, на відміну від інших респондентів, представники покоління Батьків не вважають своїми характерними рисами працьовитість $(33,8 \%)$, досвідченість $(28,4 \%)$, доброзичливість $(16,2 \%)$, обережність $(14,9 \%)$, духовність $(13,5 \%)$, жертовність $(13,5 \%)$. Але не відмічені у покоління Батьків респондентами 70-56 років, які в сімейно-рольовому аспекті ідентифікують себе з поколінною групою Прабатьків, якості доброзичливості, обережності, відданості, допитливості, самостійності можуть пояснити утруднення у їхніх відносинах (стосунках) з поколінням Батьків. I особливо привертає до себе увагу відмічена тільки респондентами-Прабатьками риса егоїстичності $(9,1 \%)$.

Описуючи габітус покоління Прабатьків, респонденти були одностайними у визначенні таких їхніх якостей: мудрі (50 \%), схильні до повчань $(45,9 \%)$, неврівноважені $(44,6 \%)$, розсудливі $(28,4 \%)$, добрі (25,7\%), турботливі $(25,7 \%)$, освічені (17,6 \%), відповідальні $(16,2 \%)$, працьовиті $(14,9 \%)$, співчутливі $(13,5 \%)$. Цікаво, що незадоволеність життям $(45,9 \%)$ і консерватизм $(36,5 \%)$, на відміну від інших опитаних, не відмітила у покоління Прабатьків лише група респондентів 7056 років.

Наступним питанням визначення соціальної поколінної ідентичності як інтегральної основи габітусу [7] був аналіз самовизначення поколінь за критерієм поведінкових стратегій (за віковим маркером i відповідно до рольового навантаження в соціальних відносинах) 3 частотою згадування смислових одиниць більш як $20 \%$. Так, за самови- 
значенням для представників покоління Дітей більш характерними $є$ риси безтурботності (54,5 5), активності (40,9\%), завзятості (31,8 \%), безвідповідальності $(27,3 \%)$, оптимізму $(27,3 \%), \quad$ легковажності $(22,7 \%)$, впертості $(22,7 \%)$, розкутості $(27,3 \%)$. Група “ДітейБатьків” додатково відмітила характеристики велелюбності (33,3\%) i самостійності $(41,7 \%)$.

Респонденти покоління Батьків вважають, що їм притаманні такі риси, як відповідальність (100\%), освіченість (40\%), моральність (40\%), раціональність (40\%), турботливість (20\%), доброзичливість (20\%), духовність (20\%), цілеспрямованість (20\%). Цікаво, що опитані в групах “Діти-Батьки” 33-21 років і “Батьки-Прабатьки” 47-34 років відмічали працьовитість (33,3 \% і 34,9 \%) і турботливість (25 \% і $43,5 \%)$.

Характеристиками самовизначення покоління Прабатьків стали якості турботливості (45,5\%), доброти $(27,3 \%)$, працьовитості $(27,3 \%)$, а за відповідями Батьків-Прабатьків 47-34 років ще й якості освіченості $(34,8 \%)$, розсудливості $(30,4 \%)$ і схильності до повчань $(21,7 \%)$.

У дослідженні відмінностей уявного образу поколінь опитані зазначили в системах “Діти - Батьки”, “Діти - Прабатьки”, “Батьки Прабатьки" відмінність габітусу саме в різному життєвому досвіді $(32,4 \%, 24,3 \%$ і 21,6 \%, відповідно). При цьому опитані зрілого віку конкретизували міжпоколінні відмінності в системі “Дітей - Прабатьків" у різному вихованні $(33,8 \%)$, у системі “Батьків - Прабатьків" розбіжності поглядів $(29,7 \%)$.

На етапі вивчення особливостей соияіального позиціонування (ентелехій) поколінь завданням дослідження було визначення соціальних настановлень, уявлень, цінностей, характерних для представників поколінь Дітей, Батьків, Прабатьків. Аналіз різнопланового ретранслювання соиіальних настановлень, набутих протягом життя, дав змогу довести мінливість спрямованості дій, оціночного реагування поколінь. Так, атитюд покоління Дітей, на думку опитаних респондентів, виражається в цілеспрямованій поведінці щодо саморозвитку (21,3 \%) i подолання соціальної незахищеності (14,7 \%). Представники покоління Батьків, спираючись на свій життєвий досвід $(21,3 \%)$, виявляють готовність до самореалізації в кар'єрі (18,7\%); у виборі поведінкових стратегій означилася тенденція до уникання конфліктів (12\%) і залагодження непорозумінь засобами спілкування (10\%). На жаль, частина респондентів вважає характерною ознакою покоління Батьків зневіреність у майбутньому. 3 огляду на виконання в житті різних поколінних ролей це песимістичне настановлення опитані представили в різному 
відсотковому співвідношенні: у поколінній групі "Прабатьків" відмітили 27,3\%, 13 \% “Батьків-Прабатьків”, 20 \% “Батьків", 16,7 \% “Дітей-Батьків” і лише 4,5\% в групі “Дітей”. Спільне для всіх відчуття безнадійності і безперспективності респондентів може мати лише одне пояснення - соціальні, політичні, економічні негаразди не оминають всі вікові групи, але найбільш уразливими є люди літнього віку. I ще важливим соціальним настановленням покоління Прабатьків опитані назвали розуміння цінності життя $(10,7 \%)$ як найвищого соціально значущого ресурсу.

Що ж до соиіальних уявлень, то для покоління Дітей орієнтацію на навчання як організовану діяльність засвоєння суспільного досвіду зазначили $28 \%$ опитаних. Покоління Батьків, на думку респондентів, у соціальних уявленнях переходить на наступний етап розвитку - осмислення життєвих знань (25,3\%) шляхом узагальнення набутої інформації, досвіду пережитих подій, визначення логічно-наслідкових зв'язків елементів соціального буття - предметів, явищ, процесів; свідомого ставлення до часу (16\%) як сформованого поняття, адекватного сприймання сьогодення, реконструювання минулого i прогнозування майбутнього, розуміння необхідності вимірювання i раціонального використання часу; шанобливого ставлення до оточення $(14,7 \%)$ як шанування прав, переконань, свобод інших; досягнення соціальної безпеки (12\%) як стану життєдіяльності людини та суспільства, яка, на думку В. Скуратівського [8], характеризується сформованою, сталою соціальною системою забезпечення соціальних умов діяльності особистості, іiі соціальної захищеності, стійкості до впливу чинників, що підвищують соціальний ризик. У соціальних уявленнях покоління Прабатьків на перший план виходить значущість громадянської позиції (9,3\%), відповідальне осмислене ставлення не тільки до участі у виборчих кампаніях, а й до виконання громадських обов'язків.

На основі аналізу виокремлених групових иінностей як характерні для покоління Дітей респонденти визначили цінності кохання (20\%), сім'ї (13,3\%), життя батьків (12\%), свободи (12\%), дружби (12\%); для покоління Батьків - сім’ї (29,3\%), дітей (20\%), саморозвитку $(16 \%)$, роботи (12\%); для покоління Прабатьків - цінності життя $(18,7 \%)$ і онуків $(10,7 \%)$ як продовження себе в майбутньому. Так, 3 огляду на результати аналізу відповідей респондентів на шляху розвитку, зміни соціальних ролей і при переході з покоління в покоління відбувалася поступова трансформація цінностей, породжених життевими потребами любити і дружити, жити в родині, набувати здатності діяти відповідно до власних інтересів, визначати цілі, усвідомлювати мету існування, брати на себе відповідальність за себе та інших. 3 ві- 
ком першочергові особисті і групові цінності становлення доповнювалися завданнями досягнення матеріального добробуту, забезпечення економічної стабільності, прямування до саморозвитку і професійної самореалізації. I, як результат, становлення покоління, перехід у статус Прабатьків переважно визначався досягненням вищих цінностей загальнолюдського масштабу - розуміння унікальності життя людини i можливості знайти продовження себе в нащадках. Отже, з віком і змінами умов життєдіяльності відбувається трансформація поколінних цінностей, які виникають або зникають, поступово, через усвідомлення переходять у переконання, ціннісні орієнтації, змінюють пріоритетність значущих на певних етапах онтогенезу явищ, ідей, діяльності, що впливає на соціальну позицію поколінь.

На наступному кроці дослідження з огляду на особливості соціально-психологічних відмінностей габітусу і соціального позиціонування (ентелехій) відповідно до критеріїв диференціації поколінь визначено узагальнені характеристики ментальних систем поколінь (табл. 2). Так, поколінню Дітей за критерієм вікових психологічних характеристик притаманні активність, завзятість, велелюбність, безвідповідальність, оптимістичність, незалежність, легковажність, товариськість, розкутість, комунікабельність, допитливість, цілеспрямованість, упертість. За критерієм поведінкових стратегій у соціальних настановленнях покоління превалює готовність розвиватись, долати соціальну незахищеність; у соціальних уявленнях осмисленою стає потреба в навчанні як запоруці майбутньої самореалізації; у цінностях на перший план виходять кохання, сім'я, батьки, свобода, дружба. За критерієм соичіально-історичних подій, який представляє нові зразки моделей відносин, поведінки, сформованих у період становлення, у габіmyci поколінь Дітей визначено залежність від історичних подій прояву якостей ерудованості; прагнення “отримати все одразу” (за критерієм $\chi^{2}, p<0,01 *$ ); безтурботності, вимогливості, прагматичності $\left(p<0,05^{*}\right)$; зацікавленості, некомунікабельності (цікаво, що притаманна за віковим критерієм поколінню Дітей комунікабельність під дією соціальних впливів з часом трансформується в некомунікабельність, що в подальшому зумовлює ускладнення міжпоколінного взаєморозуміння), спрямованості до незалежності, самостійності, цинічності i хаотичності (як циклічності проявів негативнихпозитивних станів) ( $p<0,1)$. Залежно від соціальних впливів набуває нових особливостей і соціальне позиціонування: навчаються щиро любити, отримують знання про сімейне життя ( $p<0,05 *)$; зростає цінність роботи, навчання, дружби $(p<0,1)$. 


\section{Таблиия 2}

Характеристики покоління Дітей

\begin{tabular}{|c|c|c|c|}
\hline \multirow{2}{*}{ Критерії } & \multicolumn{3}{|c|}{ Характеристики поколіня } \\
\hline & \multicolumn{3}{|c|}{ Габітус покоління Дітей } \\
\hline $\begin{array}{l}\text { Вікові психо- } \\
\text { логічні харак- } \\
\text { теристики } \\
\end{array}$ & \multicolumn{3}{|c|}{$\begin{array}{c}\text { активні, завзяті, велелюбні, безвідповідальні, оптимістичні, } \\
\text { незалежні, легковажні, товариські, розкуті, комунікабельн, } \\
\text { допитливі, цілеспрямовані, вперті }\end{array}$} \\
\hline \multirow{4}{*}{$\begin{array}{l}\text { Поведінкові } \\
\text { стратегії }\end{array}$} & \multicolumn{3}{|c|}{ Соціальні позичї (ентелехії) покоління Дітей } \\
\hline & $\begin{array}{l}\text { настанов- } \\
\text { лення }\end{array}$ & \multicolumn{2}{|c|}{$\begin{array}{l}\text { розвиватися, подолати соціальну незахище- } \\
\text { ність }\end{array}$} \\
\hline & уявлення & \multicolumn{2}{|l|}{ спрямованість на навчання } \\
\hline & цінності & \multicolumn{2}{|c|}{$\begin{array}{l}\text { кохання, сім'я, життя батьків, свобода, дру- } \\
\text { жба }\end{array}$} \\
\hline \multirow{7}{*}{$\begin{array}{l}\text { Соціально- } \\
\text { історичні } \\
\text { події }\end{array}$} & \multicolumn{2}{|c|}{$\begin{array}{c}\text { Надбані (активізовані) якості габітусу } \\
\text { під впливом історичних подій }\end{array}$} & $\begin{array}{l}\text { Asymp. } \\
\text { Sig }\end{array}$ \\
\hline & \multicolumn{2}{|c|}{ ерудованості; прагнення “отримати все одразу” } & $p<0,01 *$ \\
\hline & \multicolumn{2}{|c|}{ безтурботності, вимогливості, прагматичності } & $p<0,05^{*}$ \\
\hline & \multicolumn{2}{|c|}{$\begin{array}{l}\text { зацікавленості, некомунікабельності, незалеж- } \\
\text { ності, самостійності, цинічності, хаотичності }\end{array}$} & $p<0,1$ \\
\hline & \multicolumn{2}{|c|}{$\begin{array}{c}\text { сочіальні позичї (ентелехії), сформовані } \\
\text { під впливом історичних подій }\end{array}$} & $\begin{array}{l}\text { Asymp. } \\
\text { Sig }\end{array}$ \\
\hline & \multicolumn{2}{|c|}{ любити; здобути знання про сімейне життя } & $p<0,05^{*}$ \\
\hline & \multicolumn{2}{|c|}{$\begin{array}{l}\text { оволодіти професійними знаннями, навчатися, } \\
\text { дружити }\end{array}$} & $p<0,1$ \\
\hline
\end{tabular}

Міжпоколінне оцінювання визначило такі притаманні групі Батьків за критерієм вікових психологічних характеристик якості: відповідальності, працьовитості, турботливості, освіченості, доброзичливості, духовності, жертовності, цілеспрямованості, відданості, допитливості, раціональності, самостійності, егоїстичності (табл. 3). За другим критерієм - поведінкових стратегій - Батьки проявляють соціальні настановлення щодо отримання і використання життєвого досвіду, спрямованості реалізуватись у професії, вірити в майбутнє, уникати конфліктів, спілкуватися з іншими. Так, у процесі розвитку, становлення на етапі розквіту покоління знову відбувається зміна щодо ставлення до необхідності підтримувати суспільні контакти. Формується ланцюжок "спрямованість до спілкування - уникнення спілкування - спрямованість до спілкування": покоління Дітей, яке виконує відповідні соціальні ролі, проявляє потребу спілкуватись, поступово, з переходом до ролі “Діти-Батьки” починає уникати контактів і знову, на наступному етапі, тепер уже виконуючи соціальну роль 
покоління Батьків, розуміє необхідність пошуку засобів підтримання відносин.

Таблиця 3

Характеристики покоління Батьків

\begin{tabular}{|c|c|c|c|}
\hline \multirow{2}{*}{ Критерії } & \multicolumn{3}{|c|}{ Характеристики покоління } \\
\hline & \multicolumn{3}{|c|}{ Габітус покоління Батьків } \\
\hline $\begin{array}{l}\text { Вікові психо- } \\
\text { логічні харак- } \\
\text { теристики }\end{array}$ & \multicolumn{3}{|c|}{$\begin{array}{l}\text { відповідальні, працьовиті, турботливі, освічені, доброзич- } \\
\text { ливі, духовні, жертовні, цілеспрямовані, віддані, допитливі, } \\
\text { раціональні, самостійні, егоїстичні }\end{array}$} \\
\hline \multirow{4}{*}{$\begin{array}{l}\text { Поведінкові } \\
\text { стратегії }\end{array}$} & \multicolumn{3}{|c|}{ Соціальні позиції (ентелехії) покоління Батьків } \\
\hline & $\begin{array}{l}\text { наста- } \\
\text { нов- } \\
\text { лення }\end{array}$ & \multicolumn{2}{|c|}{$\begin{array}{l}\text { отримувати і використовувати життєвий досвід, } \\
\text { реалізуватись у професії, вірити в майбутнє, } \\
\text { уникати конфліктів, спілкуватися }\end{array}$} \\
\hline & $\begin{array}{c}\text { уявлен- } \\
\text { ня }\end{array}$ & \multicolumn{2}{|c|}{$\begin{array}{l}\text { прагнення до свідомого використання знань, } \\
\text { часу; шанобливе ставлення до інших, отримання } \\
\text { соціальної безпеки }\end{array}$} \\
\hline & цінності & \multicolumn{2}{|l|}{ сім'я, діти, саморозвиток, робота } \\
\hline \multirow{8}{*}{$\begin{array}{l}\text { Соціально- } \\
\text { історичні } \\
\text { події }\end{array}$} & \multicolumn{2}{|c|}{$\begin{array}{c}\text { Надбанні (активізовані) якості габітусу } \\
\text { під впливом історичних подій }\end{array}$} & Asymp. Sig \\
\hline & \multicolumn{2}{|c|}{ невитриманості } & $p<0,01 *$ \\
\hline & \multicolumn{2}{|c|}{ моральності } & $p<0,05^{*}$ \\
\hline & \multicolumn{2}{|c|}{ заклопотаності, обережності } & $p \leq 0,1$ \\
\hline & \multicolumn{2}{|c|}{$\begin{array}{c}\text { Сочіальні позичї, сформовані під впливом } \\
\text { історичних подій }\end{array}$} & Asymp. Sig \\
\hline & \multicolumn{2}{|c|}{ передати знання дітям, уникати конфліктів } & $p<0,01 *$ \\
\hline & \multicolumn{2}{|c|}{ поважати інших, цінувати здоров’я, безпеку } & $p<0,05^{*}$ \\
\hline & \multicolumn{2}{|c|}{$\begin{array}{l}\text { співпрацювати, довіряти, поважати інше сві- } \\
\text { тобачення }\end{array}$} & $p<0,1$ \\
\hline
\end{tabular}

На цю мінливість слід звертати увагу, проектуючи технології оптимізації міжпоколінних відносин (стосунків). В уявленнях покоління Батьків визначено спрямованість на свідоме використання знань, часу, шанобливе ставлення до інших й отримання соціальної безпеки як державної гарантії стабільності. Головними цінностями покоління Батьків стають сім'я, діти, саморозвиток і стабільна робота.

I, нарешті, у наступному критерії залежно від впливу соціальноісторичних подій проявляються невитриманість ( $p<0,01 *)$, моральність $(p<0,05 *)$, заклопотаність, обережність $(p \leq 0,1)$. Що ж до соціальних позицій (третій критерій), то історичні подї̈ навчають Батьків майстерності передавання досвіду дітям, приходить розуміння необхідності уникати конфліктів у спілкуванні $(p<0,01 *)$, 3 повагою ставитися до 
інших, берегти здоров'я, уникати ризикових ситуацій $(p<0,05 *)$. Покоління Батьків опановує досвід співпраці, довіри, формується повага до іншого світобачення $(p<0,1)$.

Психологічні характеристики поколінної групи Прабатьків за віковим критерієм представлені якостями розсудливості, доброти, відповідальності і працьовитості (табл. 4).

Таблиия 4

Характеристики покоління Прабатьків

\begin{tabular}{|c|c|c|c|}
\hline \multirow{2}{*}{ Критерії } & \multicolumn{3}{|c|}{ Характеристики покоління } \\
\hline & \multicolumn{3}{|c|}{ Габітус покоління Прабатьків } \\
\hline $\begin{array}{c}\text { Вікові психо- } \\
\text { логічні харак- } \\
\text { теристики }\end{array}$ & \multicolumn{3}{|c|}{ розсудливі, добрі, відповідальні, працьовиті } \\
\hline \multirow{4}{*}{$\begin{array}{l}\text { Поведінкові } \\
\text { стратегії }\end{array}$} & \multicolumn{3}{|c|}{ Соціальні позищії (ентелехії) покоління Прабатьків } \\
\hline & настановлення & \multicolumn{2}{|c|}{ раціональне використання часу життя } \\
\hline & уявлення & \multicolumn{2}{|c|}{ свідоме ставлення до громадської позиції } \\
\hline & цінності & \multicolumn{2}{|l|}{ життя, онуки } \\
\hline \multirow{7}{*}{$\begin{array}{l}\text { Соціально- } \\
\text { історичні } \\
\text { події }\end{array}$} & \multicolumn{2}{|c|}{$\begin{array}{c}\text { Надбані (активізовані) під впливом історич- } \\
\text { них подій якості габітусу }\end{array}$} & Asymp. Sig \\
\hline & \multicolumn{2}{|c|}{ мудрості, неврівноваженості, незадоволеності } & $p=0,000 * *$ \\
\hline & \multicolumn{2}{|c|}{ буркотливості, відданості, освіченості } & $p \leq 0,05^{*}$ \\
\hline & \multicolumn{2}{|c|}{ схильності до повчань, консерватизму } & $p<0,01^{*}$ \\
\hline & \multicolumn{2}{|c|}{$\begin{array}{l}\text { освіченості, емпатійності, турботливості, від- } \\
\text { повідальності }\end{array}$} & $p<0,1$ \\
\hline & \multicolumn{2}{|c|}{$\begin{array}{c}\text { Сочіальні позиції, сформовані під впливом } \\
\text { історичних подій }\end{array}$} & Asymp. Sig \\
\hline & \multicolumn{2}{|c|}{ уникати самотності, цінувати життя } & $p<0,1$ \\
\hline
\end{tabular}

За критерісм поведінкових стратегій настановленням Прабатьків стає необхідність раціонально використовувати час життя; сформованим уявленням $\epsilon$ свідома громадянська позиція, а головними цінностями - життя й онуки. Але за критерієм соціально-історичних подій залежно від соціальних впливів у Прабатьків знаходить прояв позитивно-негативна різноманітність якостей мудрості, неврівноваженості, незадоволеності $(\boldsymbol{p = 0 , 0 0 0 * * )}$, буркотливості, відданості, освіченості $\left(p \leq 0,05^{*}\right)$, схильності до повчань і консерватизму $\left(p<0,01^{*}\right)$, освіченості, емпатійності, турботливості, відповідальності $(p<0,1)$. У соціальних позиціях залежно від історичних періодів знаходимо, на рівні тенденцій, намагання уникати самотності і свідомо використовувати плинний час життя $(\mathrm{p}<0,1)$. 
Отже, аналіз результатів діагностики підтверджує гіпотезу щодо впливу соціальних умов становлення на особливості ментальних систем поколінних груп, зумовлених унікальністю ментальності як онтологічної характеристики зв'язків психологічного і соціального, сформованої в результаті поєднання габітусу і соиіальних позииій, i впливом об'єктивних соціальних факторів, значущих подій, особливих економічних, культурних умов становлення поколінь на формування характеристик ментальних систем, які опосередковують змістовність і результативність поколінного спілкування. Отримані результати дають змогу припустити можливість проектування характеристик поколінних груп Дітей, Батьків, Прабатьків на інші часові історичні відрізки як універсальних онтологічних показників вікових трансформацій. Це окреслює перспективу подальшого соціальнопсихологічного дослідження міжпоколінних відносин, виявлення мінливості комунікативних спрямувань, здатності до здійснення суспільних впливів відповідно до вікової динаміки, прояву психологічних якостей і пошуку ефективних засобів покращення взаєморозуміння між суб’єктами, які перебувають на різних стадіях-етапах розвитку.

\section{Висновки}

1. Обгрунтовано необхідність дослідження характеристик ментальних систем поколінних груп для забезпечення оптимальних форм конструювання технологій взаєморозуміння і розширення можливостей діалогічного поколінного спілкування.

2. Відповідно до обгрунтованих напрямків інформаційного пошуку представлено хід дослідження характеристик ментальних систем поколінних груп, біологічні, культурні, соціальні конотації яких сформовані під впливом значущих історичних подій та опосередковують формування загальних тенденцій прояву поколінних соціальних настановлень, соціальних уявлень, цінностей.

3. Відповідно до психологічних механізмів диференціації та інтеграції проаналізовано узагальнені показники особливостей поколінних груп (соціальних позицій (ентелехій), габітусу), самовизначення поколінних груп за віковим маркером щодо рольового навантаження в соціальних відносинах. Визначено соціальні настановлення, уявлення, цінності, характерні для представників поколінь Дітей, Батьків, Прабатьків.

4. Аналіз відмінностей габітусу, особливостей соціального позиціонування (ентелехій) та узагальнених характеристик ментальних систем поколінь Дітей, Батьків, Прабатьків підтвердив гіпотезу щодо впливу соціальних умов становлення на особливості ментальних систем поколінних груп. 


\section{Лimepamypa}

1. Кочубейник О. М. Соціальний діалог: соціальні та психологічні передумови комунікативності / О. М. Кочубейник // Наукові студії із соціальної та політичної психології : зб. статей / Нац. акад. пед. наук України, Ін-т соц. та політ. психології. - К. : Міленіум, 2014. - Вип. 34 (37). - С. 150-160.

2. Горохов В. Ф. О соотношении категорий “социальная общность” и “социальная группа” / В. Ф. Горохов, Н. Н. Васнева // Вестник Тамбовского университета. Серия: Гуманитарные науки. - 2014. - № 4 (132). - С. 1221.

3. Довгань Н. О. Система соціально-психологічного простору поколінь: формування і відносини (стосунки) поколінь / Н. О. Довгань // Наукові студії із соціальної та політичної психології : зб. статей / Нац. акад. пед. наук України, Ін-т соц. та політ. психології. - К. : Міленіум, 2016. - Вип 38 (41). - C. 139-151.

4. Bourdieu P. Choses dites / Pierre Bourdieu. - Paris : Minuit, 1987. - 229 p.

5. Мангейм К. Проблема поколений (1928). Социология молодежи [Электронный ресурс] : Электрон. энцикл. / К. Мангейм ; под ред. В. А. Лукова. - Режим доступа: http://www.soc-mol.ru/encyclopaedia/studies/155problema-pokoleniy-1928.html

6. Сосновская А. М. Журналист: личность и профессионал (психология идентичности) [Электронный ресурс] / А. М. Сосновская . - СПб. : Роза мира, 2005. - 206 с. - Режим доступа : http://www.evartist.narod.ru /text19/037.htm

7. Элиас Н. Общество индивидов / Норберт Элиас. - М. : Праксис, 2001. $336 \mathrm{c}$.

8. Скуратівський В. Соціальна безпека українського суспільства та шляхи ії забезпечення / В. Скуратівський, О. Линдюк // Вісник Національної академії державного управління при Президентові України. - 2011. - № 3. C. 194-204.

\section{References}

1. Kochubeynyk, O. M. (2014). Sotsialnyi dialoh: sotsialni ta psykholohichni peredumovy komunikatyvnosti [Social dialogue: social and psychological backgrounds of communicativity]. Naukovi studii iz sotsialnoi ta politychnoi psykholohii [Scientific Studies in Social and Political Psychology], 34 (37), 150-160 (ukr).

2. Gorokhov, V. F. and Vasneva, N. N. (2014). O sootnoshenii kategoriy "sotsialnaya obshchnost" i "sotsialnaya gruppa" [About correlation between "social community" and "social group" categories]. Vestnik TGU. Gumanitarnyye nauki [Bulletin of Tambov University. Series: Humanitarian sciences], 4 (132), 12-21 (rus).

3. Dovgan, N. O. (2016). Systema sotsialno-psykholohichnoho prostoru pokolin [The system of social and psychological generational space: forming and relationships between generations]. Naukovi studii iz sotsialnoi ta politychnoi psykholohii [Scientific Studies in Social and Political Psychology], 38 (41), 139-151 (ukr). 
4. Bourdieu, P. (1987). Choses dites. Paris: Minuit (french).

5. Mangeym, K. (1928). Problema pokoleniy [Issue of Generations]. In V. A. Lukov (Eds.). Sotsiologiya molodezhi: Elektronnaya entsiklopediya [Sociology of Youth: E-Encyclopedia], http://www.socmol.ru/encyclopaedia/studies/155-problema-pokoleniy-1928.html (rus).

6. Sosnovskaya, A. M. (2005). Zhurnalist: lichnost i professional (psihologiya identichnosti) [Journalist: personality and professional (Identity psychology)], http://www.evartist.narod.ru/text19/037.htm (rus).

7. Elias, N. (2001). Obshchestvo individov [Die Gesellschaft der Individuen] [Society of individuals]. Moscow: Praksis Publ. (rus).

8. Skurativskyi, V. and Lyndiuk, O. (2011). Sotsialna bezpeka ukrainskoho suspilstva ta shliakhy ii zabezpechennia [Social security of Ukrainian society and ways to ensure it]. Visnyk Natsionalnoi akademii derzhavnoho upravlinnia pry Prezydentovi Ukrainy [Bulletin of National Academy for Public Administration under the President of Ukraine], 3, 194-204 (ukr).

\section{features \\ Dovgan N. O. The research of generational communities' mentality}

The methodological research basis and the description of generation community mentality features are presented to create prerequisites for understanding optimization and broadening of dialogic generational communications. The main directions of the research are identified and substantiated. They are determination of the informational and meaningful foundations of generational mentality, the sample characteristics as for its social, cultural, historic area, peculiarities of social and psychological differences in generational habits and social positions (entelechies). According to the formed criteria of differentiation and functional boundaries between generations, three generations of Children, Parents, and Grandparents are singled out as a result of clustering array of the experimental data. The features of the social and psychological differences in habits and social positions (entelechies) of generations are analyzed. The determined generalized characteristics of the mental systems of generation communities allowed us to confirm assumptions about uniqueness and influence of relationships delivery of the mental features of generation communities, formed under influence of historical events.

Key words: generation community, mentality, criteria for differentiation, social positions (entelechies), habits.

(C) Довгань Н. О. 